(RESEARCH ARTICLE)

\title{
Effectiveness of arbuscular mycorrhiza fungi propagules to growth of mustard plant (Brassica juncea L.) under net house treatment
}

\author{
Halim ${ }^{1,}{ }^{*}$, Arma Makmur Jaya ${ }^{1}$, Erawan Dedi ${ }^{1}$ and Rembon Fransiscus Suramas ${ }^{2}$ \\ ${ }^{1}$ Department of Agrotechnology, Faculty of Agriculture, Halu Oleo University, Southeast Sulawesi, Indonesia. \\ ${ }^{2}$ Department of Soil Science, Faculty of Agriculture, Halu Oleo University, Southeast Sulawesi, Indonesia.
}

Publication history: Received on 23 March 2019; revised on 16 April 2019; accepted on 28 April 2019

Article DOI: https://doi.org/10.30574/wjarr.2019.2.1.0022

\begin{abstract}
The purpose of this study was to determine the growth of mustard plant (Brassica juncea L.) responses to arbuscular mycorrhiza fungi under net house treatment. This research was conducted in net house of SindangKasih village, District of West Ranomeeto, South Konawe, and Laboratory of the Faculty Forestry and Environmental Science Halu Oleo University Kendari, Indonesia. This study used a Completely Randomized Design (CRD), which consists of 5 treatments i.e.: with out of mycorrhiza fungi propagules (M0), mycorrhiza fungi propagules as $25 \mathrm{~g}$ per polybag (M1), mycorrhiza fungi propagules as $50 \mathrm{~g}$ per polybag (M2), mycorrhiza fungi propagules as $75 \mathrm{~g}$ per polybag (M3), mycorrhiza fungi propagules as 100 g per polybag (M4). The variables observed were plant height, leaf number, total leaf area, specific leaves area and percentage of mycorrhiza fungi infection on rooting of mustard plant. The result of the research showed that application of the mycorrhiza fungi propagules at doses of $75 \mathrm{~g}$ per polybag given the highest of total leaves area as such as $1800.8 \mathrm{~cm}^{2}$, application the mycorrhiza fungi propagules at doses of $100 \mathrm{~g}$ per polybag given the highest specific of leaves area as such as $113.7 \mathrm{~cm} 2$, and application the mycorrhiza fungi at doses $25 \mathrm{~g}$ per polybag given the highest of percentage of mycorrhiza fungi infection to rooting of mustard plant as such as $14.90 \%$.
\end{abstract}

Keywords: Mustard plant; Mycorrhiza fungi; Plantings media; Propagules; Rootings infection

\section{Introduction}

The mustard plant is a horticultural crop that has high economic value and good prospect to be developed widely in Indonesia. The existence of mustard plants can't be separated from the daily needs of the people who consumed both after processed and as fresh vegetables. The part of the mustard plant that is consumed and the economic value is the leaves. In the leaves of mustard plants contain calories as much as $22.0 \%$, protein, vitamins, calcium, phosphorus, Vitamins A, B, C and fiber are useful for digestion health [1].

The average yield of mustard plants grown by the community is still relatively low. One of the causes of low production of mustard plants is low soil fertility, conventional farming methods and excessive use of chemical fertilizers that potentially leave residues in the soil. The chemical fertilizers have contributed significantly toward the pollution water, air and soil. Various efforts based on principles conservation and eco-friendly natural sources to improve soil fertility natural of this soil types were carried out. Data et al [2] reported that several of the factors responsible for low yield are poor soil, out dated varieties and lack modern technologies used for cropping. According Halim et al [3], that's one of method to improving soil fertility is using the mycorrhiza fungi. The result of research Halim et al [4], showed that higher fresh and dry plant weight of mustard plant obtained by the application of mycorrhiza fungi.

\footnotetext{
${ }^{*}$ Corresponding author

E-mail address: haliwu_lim73@Yahoo.co.id
} 


\section{Material and methods}

\subsection{Experimental setup [2]}

This research was conducted in net house of Sindang Kasih village, District of West Ranomeeto, South Konaweand Laboratory of the Faculty Forestry and Environmental Science Halu Oleo University Kendari. The mycorrhizal fungi used in this studied was the result of propagation of Ageratum conyzoides [5]. The plants were grown in polybag ( $40 \mathrm{~cm}$ $\mathrm{x} 50 \mathrm{~cm}$ ) and study was conducted in completely randomized block design with five treatment i.e.: without mycorrhiza fungi propagules $\left(\mathrm{M}_{0}\right)$, mycorrhiza fungi propagules as $25 \mathrm{~g}$ per polybag $\left(\mathrm{M}_{1}\right)$, mycorrhiza fungi propagules as $50 \mathrm{~g}$ per polybag $\left(\mathrm{M}_{2}\right)$, mycorrhiza fungi propagules as $75 \mathrm{~g}$ per polybag $\left(\mathrm{M}_{3}\right)$, mycorrhiza fungi propagules as $100 \mathrm{~g}$ per polybag $\left(\mathrm{M}_{4}\right)$, each treatment was replicated with five replications.

\subsection{Preparation planting media [2]}

Preparation of planting media; preparation of planting media include soil removal, soil cleaning from dirt, filling in polybags and basic fertilization using sterilized cow manure using oven furnace.Sowing of mustard plants; mustard plant is first put on a seedbed for 14 days, then transferred into polybag research. Application of mycorrhizal fungi; the application of mycorrhizal fungi was performed simultaneously with the transfer of mustard plants into the research polybag. The location of mycorrhizal fungi propagules is under the seeds of plants [6].Maintenance; crop maintenance includes watering done in the morning and afternoon with water volume of $500 \mathrm{ml}$ per polybag to maintain the field capacity condition.

\subsection{Observation of variable [3]}

The variables observed in this study include:

Plant height, measured from the base of the stem to the highest end of the leaves using the ruler at 7,14,21,28 and 35 Day after planting (DAP).

Number of leaves at 7,14,21,28 and 35 DAP.

Total leaves area at 7,14,21,28 and 35 DAP.

Specific leaves area at 7,14,21,28 and 35 DAP.

Percentage of mycorrhiza fungi infection, the observations were carried out using a dissecting microscope at a magnification 40x. Furthermore, mycorrhiza fungi infection was calculated by using the formula proposed by [7]:

$$
\mathrm{IP}=\frac{\mathrm{r} 1}{\mathrm{r} 1+\mathrm{r} 2} \times 100 \%
$$

Where: IP= the percentage of mycorrhiza fungi infection, $r 1=$ the number of root infected examples, $r 2=$ the number of root not infected examples.

\subsection{Data analysis [4]}

Data of each variable were observed were analyzed by variance of analysis. If the F count greater than the F table, than continued with the Duncan Multiples Range Test (DMRT) at 0.05\% confidence level.

\section{Results and discussion}

\subsection{Plant height and number of leaves [5]}

The average of plant height and number of leaves at 7, 14, 21, 28 and 35 DAP are presented in Tables 1 and 2. 
Halim et al. / World Journal of Advanced Research and Reviews, 2019, 02(01), 001-006

Table 1 Average of plant height $(\mathrm{cm})$ at 7,14,21,28 and 35 DAP

\begin{tabular}{llllll}
\hline Treatment & 7 DAP & 14 DAP & 21 DAP & 28 DAP & 35 DAP \\
\hline Without mycorrhiza fungi propagules (M0) & $5.88^{a}$ & $10.74^{a}$ & $16.80^{a}$ & $25.00^{a}$ & $29.66^{a}$ \\
Mycorrhiza fungi propagules as 25 g per polybag (M1) & $6.54^{\mathrm{a}}$ & $10.78^{\mathrm{a}}$ & $17.62^{\mathrm{a}}$ & $22.68^{\mathrm{a}}$ & $26.56^{\mathrm{a}}$ \\
Mycorrhiza fungi propagules as 50 g per polybag (M2) & $6.94^{\mathrm{a}}$ & $11.58^{\mathrm{a}}$ & $17.70^{\mathrm{a}}$ & $22.22^{\mathrm{a}}$ & $28.18^{\mathrm{a}}$ \\
Mycorrhiza fungi propagules as 75 g per polybag (M3) & $6.20^{\mathrm{a}}$ & $11.12^{\mathrm{a}}$ & $17.10^{\mathrm{a}}$ & $23.62^{\mathrm{a}}$ & $28.32^{\mathrm{a}}$ \\
Mycorrhiza fungi propagules as 100 g per polybag (M4) & $6.16^{\mathrm{a}}$ & $11.28^{\mathrm{a}}$ & $17.46^{\mathrm{a}}$ & $23.54^{\mathrm{a}}$ & $28.544^{\mathrm{a}}$ \\
\hline
\end{tabular}

The numbers are followed by the same letters in the same column, no significant based DMRT at $0.05 \%$.

Table 1 showed that's the highest average of plant height at 7 DAP, 14 DAP and 21 DAP was found in treatment of mycorrhiza fungi propagules as 50 g per polybag $\left(\mathrm{M}_{2}\right)$ respectively $6.94 \mathrm{~cm}, 11.58 \mathrm{~cm}$ and $17.70 \mathrm{~cm}$ were not significant to all other treatments. Whereas at 28 DAP and 35 DAP, the highest average of plant height was found in the treatment of without mycorrhiza propagules $\left(\mathrm{M}_{0}\right)$ were not significant with all other treatments.

Table 2 Average of leaves number (sheet) at 7,14,21,28 and 35 DAP

\begin{tabular}{|c|c|c|c|c|c|}
\hline Treatment & 7 DAP & 14 DAP & 21 DAP & 28 DAP & 35 DAP \\
\hline Without mycorrhiza fungi propagules (M0) & $4.2^{\mathrm{a}}$ & $5.8^{a}$ & $7.8^{\mathrm{a}}$ & $10.0^{\mathrm{a}}$ & $10.8^{\mathrm{a}}$ \\
\hline Mycorrhiza fungi propagules as 25 g per polybag (M1) & $4.2^{\mathrm{a}}$ & $6.2^{\mathrm{a}}$ & $8.2^{\mathrm{a}}$ & $10.6^{\mathrm{a}}$ & $11.2^{\text {a }}$ \\
\hline Mycorrhiza fungi propagules as 50 g per polybag (M2) & $4.4 \mathrm{a}$ & $6.8^{a}$ & $8.8^{a}$ & $10.8^{a}$ & $11.8^{a}$ \\
\hline Mycorrhiza fungi propagules as $75 \mathrm{~g}$ per polybag (M3) & $4.2^{\mathrm{a}}$ & $6.2^{\mathrm{a}}$ & $7.6^{\mathrm{a}}$ & $10.2^{\mathrm{a}}$ & $12.0^{\mathrm{a}}$ \\
\hline Mycorrhiza fungi propagules as 100 g per polybag (M4) & $4.6^{a}$ & $6.4^{a}$ & $8.4^{\mathrm{a}}$ & $11.6^{\mathrm{a}}$ & $12.6^{\mathrm{a}}$ \\
\hline
\end{tabular}

The numbers are followed by the same letters in the same column, no significant based DMRT at $0.05 \%$.

Table 2 showed that's the highest average of leaves number at 7 DAP occurred at treatment of mycorrhiza fungi propagules as 100 g per polybag $\left(\mathrm{M}_{4}\right)$ as 4.6 sheet was not significant to all other treatments. Whereas at 14 DAP and $28 \mathrm{DAP}$, the highest average of leaves number at treatment of mycorrhiza fungi propagules as $50 \mathrm{~g}$ per polybag ( $\mathrm{M}_{2}$ ) respectively6.8 sheet and 8.8 sheet were not significant with all other treatments. The highest average of leaves number on observation 28 DAP and 35 DAP occurred at the treatment mycorrhiza fungi propagules as $100 \mathrm{~g}$ per polybag (M) respectively 11.6 sheet and 12.6 sheet were not significant with all other treatments.

The result of this research indicated that mycorrhiza fungi are not effective in improving plant height and the number of leaves of mustard plants. This is related to the mycorrhiza function of absorbing nutrients Phosfor, while the growth of mustard more requires Nitrogen element. This is supported by the results of research Erawan et al [8] that mustard plants require urea fertilizer during its growth, especially for the formation of stems and the number of plant leaves. According to Arinong et al [9] that's the growth of plant height is always followed by the development of the number of leaves.

\subsection{Totals and specific leaves area [6]}

The average of total leaves area and specific leaves area were presented in Tables 3 and 4 .

Table 3 Average of total leaves area (cm2) at 35 DAP

\begin{tabular}{ll}
\hline Treatment & Average of Total Leaves Area (cm²) \\
\hline Without mycorrhiza fungi propagules (M0) & $1209.1^{\mathrm{b}}$ \\
Mycorrhiza fungi propagules as 25 g per polybag (M1) & $1208.6^{\mathrm{b}}$ \\
Mycorrhiza fungi propagules as 50 g per polybag (M2) & $1271.1^{\mathrm{b}}$ \\
Mycorrhiza fungi propagules as 75 g per polybag (M3) & $1800.8^{\mathrm{a}}$ \\
Mycorrhiza fungi propagules as 100 g per polybag (M4) & $1586.4^{\mathrm{a}}$ \\
& $2=302.4$ \\
DMRT 0.05\% & $3=317.7$ \\
& $4=325.9$ \\
& $5=333.1$ \\
\hline
\end{tabular}


Table 3 shows that the highest total leaves area occurring at treatment of mycorrhiza fungi propagules as $75 \mathrm{~g}$ per polybag $\left(\mathrm{M}_{3}\right)$ as $1800.8 \mathrm{~cm}^{2}$ was not significant with treatment of mycorrhiza fungi propagules as $100 \mathrm{~g}$ per polybag $\left(\mathrm{M}_{4}\right)$, but significantly different from all other treatments.

Table 4 Average of specific leaves area $\left(\mathrm{cm}^{2}\right)$ at 35 DAP

\begin{tabular}{|c|c|}
\hline Treatment & $\begin{array}{l}\text { Average of Specific Leaves Area } \\
\left(\mathrm{cm}^{2}\right)\end{array}$ \\
\hline Without mycorrhiza fungi propagules (M0) & $78.7^{c}$ \\
\hline Mycorrhiza fungi propagules as 25 g per polybag (M1) & $85.0 \mathrm{bc}$ \\
\hline Mycorrhiza fungi propagules as 50 g per polybag (M2) & $93.6^{b}$ \\
\hline Mycorrhiza fungi propagules as 75 g per polybag (M3) & $121.0^{\mathrm{a}}$ \\
\hline \multirow[t]{2}{*}{ Mycorrhiza fungi propagules as 100 g per polybag (M4) } & 113.7 a \\
\hline & $2=13.7$ \\
\hline \multirow[t]{3}{*}{ DMRT $0.05 \%$} & $3=14.3$ \\
\hline & $4=14.7$ \\
\hline & $5=15.0$ \\
\hline
\end{tabular}

The numbers are followed by the same letters in the same column, no significant based DMRT at $0.05 \%$.

Table 4, showed that's the highest specific leaf area occurred at treatment of mycorrhiza fungi propagules as $100 \mathrm{~g}$ per polybag $\left(\mathrm{M}_{4}\right)$ as $113.7 \mathrm{~cm}^{2}$ which was not significant with treatment of mycorrhiza fungi propagules as $75 \mathrm{~g}$ per polybag $\left(\mathrm{M}_{3}\right)$, but it significantly different from all other treatments.

The result of research showed that the highest total leaves area occurring at treatment of mycorrhiza fungi propagules as $75 \mathrm{~g}$ per polybag $\left(\mathrm{M}_{3}\right)$ as $1800.8 \mathrm{~cm}^{2}$ was not significant with treatment of mycorrhiza fungi propagules as $100 \mathrm{~g}$ per polybag $\left(\mathrm{M}_{4}\right)$, but significantly different from all other treatments. According to the results of research Marschner and Dell [10] that mycorrhiza fungi infections cause changes in plant roots growth and activity through the formation of an external mycelia that has an impact on increasing nutrient and water uptake.According to Talanca and Adnan [11] mycorrhiza fungi develop in cortical tissue, where the infection process is affected by root anatomy and plant life. In addition, plant roots have a metabolic rate 2-4 times higher when compared with uninfected plant roots by mycorrhizal fungi [12]. Sadaghiani [13] reported that there was an increase in Nitrogen (N), Phosphorus (P), Potassium (K), Calcium (Ca) and Magnesium (Mg) uptake by plants when given mycorrhizal fungi. Similar to those reported by Maryam et al [14] thearbuscular mycorrhiza fungi can be helpful in counteracting the saline stress and maintaining the plant growth and development of $B$. juncea.

\subsection{Percentage Infection of Mycorrhiza Fungi (\%) [7]}

Table 5 Average of percentage infection of mycorrhiza fungi on mustard plant rootings

\begin{tabular}{ll}
\hline Treatment & $\begin{array}{l}\text { Average of Percentage Infection of } \\
\text { Mycorrhiza Fungi (\%) }\end{array}$ \\
\hline Without mycorrhiza fungi propagules (M0) & $0.00^{\mathrm{b}}$ \\
Mycorrhiza fungi propagules as 25 g per polybag (M1) & $14.90^{\mathrm{a}}$ \\
Mycorrhiza fungi propagules as 50 g per polybag (M2) & $9.15^{\mathrm{a}}$ \\
Mycorrhiza fungi propagules as 75 g per polybag (M3) & $13.28^{\mathrm{a}}$ \\
Mycorrhiza fungi propagules as 100 g per polybag (M4) & $9.13^{\mathrm{a}}$ \\
$2=1.18$ \\
$3=1.24$ \\
$4=1.27$ \\
DMRT 0.05\% & $5=1.46$ \\
\hline \multicolumn{2}{c}{ The numbers are followed by the same letters in the same column, no significant based DMRT at 0.05\%. }
\end{tabular}


Table 5, indicating that the highest percentage of mycorrhizal fungi infections occurring at treatment of mycorrhiza fungi propagules as 25 g per polybag $\left(\mathrm{M}_{1}\right)$ as $14.90 \%$ was not significant with treatments of mycorrhiza fungi propagules as 50 g per polybag $\left(\mathrm{M}_{2}\right)$, mycorrhiza fungi propagules as $75 \mathrm{~g}$ per polybag $\left(\mathrm{M}_{3}\right)$ and mycorrhiza fungi propagules as 100 g per polybag $\left(\mathrm{M}_{4}\right)$, but significantly different from with treatment of without mycorrhiza fungi propagules ( $\left.\mathrm{M}_{0}\right)$.

The result of research showed that the all rooting sample was infected mycorrihza fungi. It is similarity with the result research Husin [15] that mycorrhiza fungi can improve plant nutrition and increase growth hormones such as auxin and gibberellins. The functions of auxin as an aging root, so the roots can function longer and more nutrient absorption will occur. While gibberellins serve as stimulants and growth enlargement of plant roots primer.

\section{Conclusion}

Based on the result of research, it can be concluded that's all the treatments of mycorrhizal fungi tested had no significant effect on plant height and number of mustard plant leaves in all observations. Application of mycorrhizal fungi at a dose of $75 \mathrm{~g}$ per polybag gives the highest total leaves area as $1800.8 \mathrm{~cm}^{2}$, at doses of $100 \mathrm{~g}$ per polybag gives the highest specific leaves area as $113.7 \mathrm{~cm}^{2}$. Application of mycorrhiza fungi at a dose of $25 \mathrm{~g}$ per polybag gives the highest percentage of infection as $14.90 \%$.

\section{Compliance with ethical standards}

\section{Acknowledgments}

The author would like to thank to Rector of Halu Oleo University for the internal financial assistance through the community service scheme in 2018 and the Chairman of the Research Institute of Halu Oleo University for serviced an administrative.

\section{Disclosure of conflict of interest}

Halim, Arma Makmur Jaya, Erwan Dedi and Rembon Fransiscus Suramas declare that there is no conflict of interest that exists.

\section{References}

[1] Sunarjono H. (2007). Plant 30 Types of Vegetables. Penebar Swadaya. ISBN: 9794897213.

[2] Datta JK, Sikdar MS, Banerjee A and Mondal NK. (2012). Screening of mustard varieties under combined dosed fertilizers and subsequent soil health and biodiversity in old Alluvial soil of Burdwan, West Bengal, India. Academic Journal of Plant Sciences, 5(3)76-83.

[3] Halim, Makmur JA, Fransiscus SR andResman. (2015). Impactof mycorrhiza fungi from grassland rhizosphere and liquid organic fertilizer to the growth and yield of sweet corn on Ultisols in South Konawe, Indonesia. Journal of Agriculture, Forestry, Fisheries, 4(5)209-215.

[4] Halim, Resman andSarawa. (2016). Characterization and impact of mycorrhiza fungi isolated from weed plants on the growth and yield of mustard plant (Brassica juncea L.). Journal of Experimental Biology and Agricultural Science, 4(1), 85-91.

[5] Halim, Karimuna L, Fransiscus SR, Resman and Titin S. (2016). Growth and potential of goat weed (Ageratum conyzoides L.) as host plant for propagation of mycorrhiza fungi. Open Access Library Journal, 3(e2640), 1-8.

[6] Halim. (2009).The role of endomycorrhiza indigenous of Imperata cylindrica (L.) Beauvand Eupatorium odorata (L.) inweed and corn competitive. Dissertation (Unpublished). Graduate Programe of Padjadjaran University Bandung. Indonesia.

[7] Brian PPWC and Schultz RC. (1980). Procedures and equipment for staining large number of plant roots for endomycorrhizal Assay. Canadian Journal of Microbiology, 26(4), 536-538.

[8] Erawan D, Yani WO and Andi B. (2013). Growth and yield of mustard (Brassica juncea L.) under various dosages of Urea fertilizer. Jurnal Agroteknos, 3(1), 19-25.

[9] Arinong AR, Vandalisna and Asni. (2014). Plant growth and production mustard (Brassica juncea L) with grant of microorganisms local (MOL) and fertilizer chicken manure. Jurnal Agrisistem, 10(1), 40-46. 
[10] Marschner H and Dell B. (1994). Nutrient uptake in mycorrhiza symbiosis. Plant Soil, 159, 89-102.

[11] Talanca HA and Adnan M. (2005). Mycorrhizae and their benefits in plants. In Proceedings of the Scientific Seminar and Annual Meeting of the PEJ and PFJ of the South Sulawesi Regional Commission, 311, 315.

[12] Sieverding E. (1991). Vesicular-arbuscular mycorrhiza management in tropical agrosystems. Sonder publikation der GTZ (Germany).

[13] Sadaghiani MR, Hassana A, Barin M, Danesh YR and Sefidkon F. (2010). Effects of arbuscular mycorrhizal (AM) fungi on growth, essential oil production and nutriends uptake in basil. Journal of Medicinal Plant Research, 4(21), 2222-2228.

[14] Maryam S, Abeer H, Mohammad AA, Elsayed AA, Alqarawi AA, Mohammad NA, Parvaiz A and Salih G. (2016). Mitigation of $\mathrm{NaCl}$ stress by arbuscular mycorrhizal fungi through the modulation of osmolytes, antioxidants and secondary metabolites in mustard (Brassica juncea L.) plants. Frontiers in Plant Science, 7(869), 1-36.

[15] Husin EF. (1997). Response of several types of plants to arbuscular vesicular mycorrhiza and phosphate fertilizer on ultisol. In proceedings to use mycorrhizal fungi to increase crop production on marginal land. Indonesian Mycorrhiza Association, Jambi University.

\section{How to cite this article}

Halim, Arma MJ, Erawan D and Rembon FS. (2019). Effectiveness of arbuscular mycorrhiza fungi propagules to growth of mustard plant (Brassica juncea L.) under net house treatment. World Journal of Advanced Research and Reviews, 2(1), 01-06. 